\title{
TINGKAT KENYAMANAN LINGKUNGAN BELAJAR SEKOLAH MENENGAH ATAS (SMA) NEGERI DI KOTA DENPASAR
}

\author{
Ni Luh Gede Ambarawati ${ }^{1 *}$ I Wayan Arthana ${ }^{2}$, I Wayan Suarna ${ }^{3)}$ \\ ${ }^{1)}$ Badan Kepegawaian Daerah Provinsi Bali \\ ${ }^{2)}$ Fakultas Kelautan dan Perikanan Universitas Udayana \\ 3) Fakultas Peternakan Universitas Udayana \\ ${ }^{*}$ Email :am_dana17@yahoo.com
}

\begin{abstract}
A healthy andcomfortable school environmentis necessary, besidessupporting the learning process, it can also improve student achievement. Noiseisdisturbingin the learning process, as well as theavailability offacilities and infrastructure will greatly affectthe comfort ofthe studentsinthe school. The purpose ofthis research is to determinethe comfort level ofstate senior highschoolstudyinthe city of Denpasarin termsofnoise levels, the availability andmanagement ofschool facilities and infrastructure and student perception against school envirumental level. The research methodused isdescriptivequantitativemethod. The locationof the research wasconductedin 8 State Senior High Schoolinthe city of Denpasar. Measurements ofnoise levelsateach schoolis capturedfromninesample pointsbyusing asound level meterand surveyof schoolfacilities and infrastructurethat are environmentally friendly. The comfort level of public high school learning environment in the city of Denpasar based on the level of noise has exceeded the qualty standard $55 \mathrm{~dB}$, with the highest noise in the school yard of $73,0 \mathrm{~dB}$, which motor vechicles as the main caused. Temperature and humidity do not affect the level of comfort, because they already meet the standards. Lighting of class room in eight public high school in the city of Denpasar very well. Because it meets the quality standard. Availability and management infrastructure is optimal and adequate to support mostly high school in the city of Denpasar. Support in the facilities and infrastructure have been seen in SMAN 3 Denpasar. Almost all students in eight high school in the city of Denpasar stated that the school environment is comfortable, even SMAN 3 Denpasar stated very comfotable at around 62,85 per cent.
\end{abstract}

Keywords: Noise, Infrastructure, SchoolLearning Environment

\section{PENDAHULUAN}

Semakinberkembangnya aktivitas masyarakat perkotaan yang mencakup berbagai kegiatan disektor kehidupan seperti pemukiman, transportasi,industri dan berbagai sektor pendukung lainnya merupakan kegiatan yang potensial dapat mengubah kualitas lingkungan. Hal ini sangat berpengaruh terhadap kawasan pendidikan (sekolah) yang berlokasi di kota-kota besar seperti Kota Denpasar. Pemilihan lokasi sekolah pada awalnya didasarkan atas pertimbangan strategis sehingga sekolah berada pada jalur trasportasi utama kota atau dipinggir jalan besar yang menguntungkan bagi sekolah karena lokasi sekolah mudah dicapai oleh siswa.Namun seiring dengan perkembangan kota dan meningkatnya kebutuhan trasportasi, sekolah dinilai tidak strategis lagi dengan kenyamanan belajar siswa di sekolah (Prawira, 2011).

Kebisingan merupakan hal yang mengganggu dalam proses belajar mengajar. Sumber kebisingan di dalam kelas terjadi karena aktivitas kelas dan pengaruh kebisingan yang terjadi di luar kelas misalnya dari trasportasi, industri, pepohonan dan manusia, sebagai tambahan tetesan hujan di atas atap juga menimbulkan kebisingan menurut Shield and Dockrell (2003).

Tingkat kenyamanan lingkungan belajar di sekolah juga mencakup lingkungan fisik, sosial, budaya, politis, dan nilai-nilai. Lingkungan fisik terdiri atas lingkungan alam dan lingkungan buatan manusia. Adanya pengelolaan dan ketersediaan sarana dan prasarana pendukung yang memadai di lingkungan belajar sekolah, akan mempengaruhi tingkat kenyamanan belajar siswa. Salah satu faktor kenyamanan proses belajar mengajar ditentukan oleh keadaan lingkungan tempat dimana proses tersebut dilakukan. Temperatur dan kelembaban ruangan belajar dinilai sangat mempengaruhi kelancaran proses tersebut. Temperatur yang terlalu panas atau dingin dan tingkat kelembaban yang tinggiatau rendah dapat menyebabkan ketidaknyamanan bagi pengguna ruangan. 


\section{METODOLOGI}

\subsection{Lokasi dan Waktu Penelitian}

Lokasi penelitian adalah lingkungan belajar di delapan Sekolah Menengah Atas (SMA) negeri di Kota Denpasar. Waktu penelitian selama tiga bulan dimulai pada bulan Januari s/d Maret 2015.

\subsection{Alat dan Bahan Penelitian}

Jam dan Stop Watch, untuk mengetahui waktuSound Level Meter sebagai alat pengukur tingkat kebisingan, Lux meter sebagai alat pengukuran pencahayaan, Calor Stress Monitor sebagai alat pengukur suhu dan kelembaban, GPS sebagai alat untuk menentukan titik sampel penelitian, Meteran, sebagai alat ukur panjang dan jarak, alat tulis dan papan clipboard, kamera digital, untuk mendokumentasikan pelaksanaan penelitian, komputer untuk kompilasi dan analisis data, lembar kuisioner yang berfungsi sebagai daftar pertanyaan yang harus dijawab dan diisi oleh siswa dan guru yang ada di sekolah tersebut, lembar survei sarana dan prasarana SMA Negeri di Kota Denpasar sebagai alat pencatatan hasil pengukuran dan pengamatan.

\subsection{Instrumen Penelitian}

Pengukuran tingkat kebisingan di masingmasingsekolah dengan mengambil sembilan titik sampel antara lain :tiga sampel di halaman sekolah Pukul : 07.00 Wita, pada saat siswa datang sekolah, Pukul 10.30 Wita (sesuai jadwal sekolah) pada saat siswa istirahat.Pukul 13.30 Wita (sesuai jadwal sekolah) pada saat siswa pulang sekolah. Pukul 09.00 Wita. Dilakukan enamsampel pengukuran terhadap ruang kelas $\mathrm{X}=\mathrm{A}$, kelas $\mathrm{XI}=\mathrm{B}$, kelas $\mathrm{XII}=\mathrm{C}$, kelas sangat nyaman,= D, kelas nyaman $=\mathrm{E}$ dan kelas tidak nyaman $=$ Fdengan menggunakan alat Sound Level Meter.

Pengukuran yang dilakukan di ruang kelas tiap SMAN di Kota Denpasar diambil seperti skema berikut :

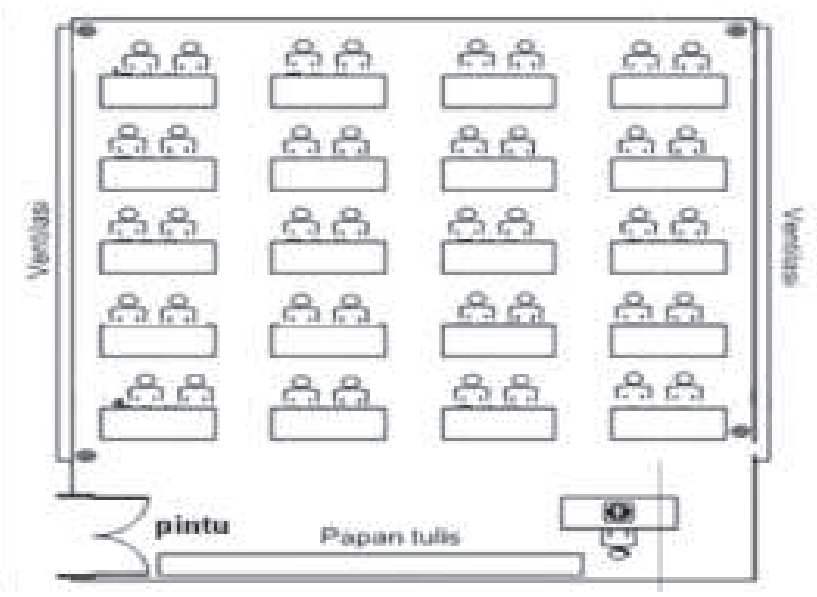

Gambar 1. Skema Titik Sampel pengukuran pada ruang kelas. Keterangan:

Titik sampel Pengukuran kebisingan.
Adapun sarana dan prasarana yang di survei antara lain Sarana prasarana untuk mengatasi permasalahan lingkungan hidup di sekolah seperti: air bersih, sampah (penyediaan tempat sampah terpisah komposter), toilet dan ruang kelas ( luas, temperatur, suhu, kelembaban dan pencahayaan kelas), Sarana prasarana pendukung pembelajaran lingkungan hidup di sekolah seperti :ruang terbuka hijau (RTH), pemanfaatan dan pengolahan air, taman/kebun sekolah, tanaman peneduh dan kantin sekolah.

\subsection{Analisis Data}

Dilakukan pengumpulkan hasil pengukuran Kebisingan, hasil survei sarana dan prasarana sekolah serta kuesioner.Membandingkan hasil pengukuran kebisingan dengan baku mutu yang mengacu pada Peraturan Gubernur Bali nomor : 8 Tahun 2007.Survei yang dilakukan secara langsung (mengukur, mencatat, memantau di lokasi) akan dianalisa dan disesuaikan dengan kreteria yang mengacu pada (Peraturan Menteri Negara Lingkungan Hidup RI Nomor : 01 Tahun 2013 tentang Perubahan Atas Peraturan Menteri Negara Lingkungan Hidup Nomor : 07 Tahun 2011 tentang Pedoman Pelaksanaan Program Adipura, Pedoman Teknis Pengendalian Faktor Resiko Kesehatan Lingkungan Di Sekolah, Direktorat Jenderal, PPM \& PL DEP.KES RI,tahun 2004 dan Keputusan Menteri Kesehatan RI Nomor :1405/MENKES/SK/ XI/2002 tentang Persyaratan Kesehatan Lingkungan Kerja Perkantoran dan Industri, Lampiran 1 dan hasil kuesioner yang berjumlah 280 (35x8) di persentasekan di tiap sekolah sebagai pendukung dari survei yang dilakukan.Setelah semua hasil diperoleh disajikan dalam bentuk tabel dan grafik untuk menggambarkan hasil pengukuran dari masing-masing sekolah menegah atas (SMA) Negeri di Kota Denpasar, dianalisis menggunakan metode deskriptif untuk mencari jawaban permasalahan dari penelitian.

\section{HASIL DAN PEMBAHASAN}

\subsection{Tingkat Kebisingan pada SMA Negeri di Kota Denpasar}

Berdasarkan baku mutu tingkat kebisingan berdasarkan keputusan Peraturan Gubernur Bali nomor : 8 Tahun 2007 ditetapkan untuk tingkat kebisingan yang diperbolehkan untuk bangunan sekolah adalah $55 \mathrm{~dB}$. Hasil pengukuran kebisingan SMA Negeri di Kota Denpasar telah melebihi baku mutu terlihat pada gambar 2 .

Grafik 2 menerangkan bahwa kebisingan SMA Negeri 4 Denpasar di ruang kelas terendah yaitu 57,7 dB hal ini disebabkan oleh ruang belajar kelas siswa tertutup dan ber AC, ada dua buah AC dengan kekuatan 1PK sehingga suara yang ada di luar 


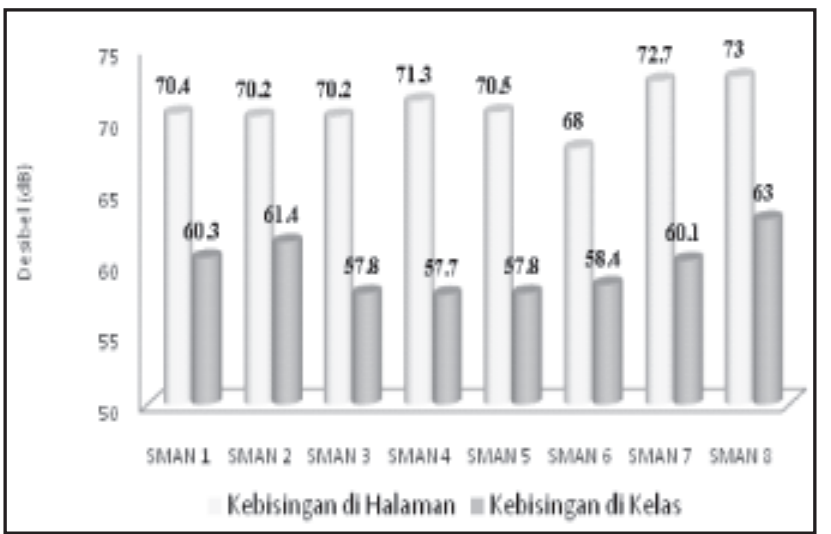

Gambar 2.Grafik Hasil Pengukuran Kebisingan

kelas tidak terlalu mengganggu. Kebisingan SMA Negeri 6 Denpasar di halaman sekolah terendah di antara sekolah yang lain yaitu sebesar $68 \mathrm{~dB}$. Hal ini karena SMA Negeri 6 Denpasar berada di kawasan yang tidak padat lalulintas, sekolah masuk ke Jl. Tukad nyali dan mempunyai pintu gerbang dua buah sehingga pada saat siswa datang ke sekolah melalui dua pintu masuk yang mengakibatkan bising terpapar menyebar di dua lokasi. Di depan/ utara sekolah terdapat perumahan yang tidak padat penduduk, warung dan bengkel sepeda motor. Sebelah barat sekolah jalan buntu dan ada kali kecil. Dalam proses belajar mengajar di ruang kelas tidak hanya dipengaruhi oleh faktor internal saja tetapi juga dipengaruhi oleh faktor eksternal yaitu kondisi lingkungan sekitarnya (Maknun J, dkk, 2010).

Kebisingan SMA Negeri 8 Denpasar di ruang kelas tertinggi diantara sekolah lain yaitu $63 \mathrm{~dB}$. Walaupun sekolah tersebut berada di kawasan yang tidak padat lalulintas karena sekolah masuk ke Jl. DAM Peraupan Penguyangan tetapi di selatan/ depan sekolah terdapat perumahan yang padat penduduk. Pengukuran hari sabtu tanggal 10 januari 2015 ada kelas tidak belajar sehingga mempengaruhi hasil pengukuran yang dilakukan. Sedangkan di halaman sekolah paling tinggi dari sekolah lain yaitu $73 \mathrm{~dB}$, karena SMA Negeri 8
Denpasar tidak mempunyai tempat parkir khusus sehingga siswa parkir di depan ruang kelas. Hampir semua areal sekolah ada sepeda motor yang parkir. Terdapat dua pintu masuk/keluar ke sekolah dan salah satu pintu menghubungkan ke SMP Negeri 12 Denpasar. Widyantoro dan Razif (2011), yang melakukan penelitian di Jl.Arif Rachman Hakim Surabaya juga mendapatkan nilai kebisingan tertinggi rata-rata $73 \mathrm{~dB}$. Menurut (Wardhana, 1995 dalam Sri Indah K, 2010) kebisingan antara 61-80 dapat menyebabkan kerusakan alat pendengaran bila kontak terjadi dalam waktu lama.

\subsection{Rangkuman Hasil Pengukuran Kebisingan}

Hasil pengukuran kebisingan yang dilakukan pada bulan Januari 2013 pada SMA Negeri di Kota Denpasar dirangkum dalam Tabel 1 :

Hasil pengukuran kebisingan di delapan SMAN di Kota Denpasar pada Tabel 2. menunjukkan bahwa kebisingan di halaman sekolah tertinggi 73,0 dB di SMAN 8 Denpasar dan kebisingan terendahnya di SMAN 6 Denpasar sebesar 68,0 dB yang penyebab utamanya adalah Kendaraan bermotor.

\subsection{Ketersediaan dan Pengelolaan Sarana dan Prasarana Sekolah}

Hasil survei pada masing-masing sekolah dalam rekapitulasi pada Tabel 2. dapat ditentukan tingkat kenyamanan lingkungan belajar siswa terhadap ketersediaan dan pengelolaan sarana dan prasarana sekolah dengan menjumlahkan nilai skor di setiap sekolah dan menunjukkan hasil survei seperti Tabel 3.

Hasil jumlah survei sarana dan prasarana pada Tabel 3. menunjukkan bahwa SMAN 3 Denpasar memperlihatkan jumlah skor tertinggi yaitu 630 dan terendah pada SMAN 6 Denpasar yaitu 470.

Untuk menentukan tingkat kenyamanan lingkungan sekolah berdasarkan ketersediaan dan pengelolaan sarana dan prasarana, dilakukan

Tabel 1. Rangkuman Hasil Pengukuran Kebisingan

\begin{tabular}{|c|c|c|c|c|}
\hline No & Sekolah & $\begin{array}{l}\text { Kebisingan }(\mathrm{dB}) \\
\text { hal }\end{array}$ & ruang kelas & Penyebab Utama Kebisingan \\
\hline 1 & SMAN 1 & 70,4 & 60,3 & - Kendaraan Bermotor \\
\hline 2 & SMAN 2 & 70,2 & 61,4 & $\begin{array}{ll}\text { - } & \text { Kendaraan Bermotor } \\
\text { - } & \text { Kegiatan sekolah }\end{array}$ \\
\hline 3 & SMAN 3 & 70,2 & 57,8 & - Siswa lain \\
\hline 4 & SMAN 4 & 71,3 & 57,7 & $\begin{array}{ll}\text { - } & \text { Kendaraan Bermotor } \\
\text { - } & \text { Kegiatan diluar sekolah }\end{array}$ \\
\hline 5 & SMAN 5 & 70,5 & 57,8 & - siswa lain \\
\hline 6 & SMAN 6 & 68,0 & 58,4 & - Kegiatan diluar sekolah \\
\hline 7 & SMAN 7 & 72,7 & 60,1 & $\begin{array}{ll}\text { - } & \text { Kendaraan Bermotor } \\
\text { - } & \text { siswa lain }\end{array}$ \\
\hline 8 & SMAN 8 & 73.0 & 63,0 & - Kendaraan Bermotor- Siswa Lain \\
\hline
\end{tabular}


Tabel 2. Rekapitulasi Hasil Survei Sarana dan Prasarana Sekolah

\begin{tabular}{|c|c|c|c|c|c|c|c|c|c|c|c|c|c|c|c|c|c|c|c|c|c|c|c|c|c|c|c|c|c|}
\hline \multirow{3}{*}{ No } & \multirow{3}{*}{ SARANAPRASARANA } & \multicolumn{28}{|c|}{ SMLA NLGLRI DI KOTA DENPASAR } \\
\hline & & \multicolumn{4}{|c|}{1} & \multicolumn{3}{|c|}{2} & \multicolumn{3}{|c|}{3} & \multicolumn{4}{|c|}{4} & \multicolumn{3}{|c|}{5} & \multicolumn{4}{|c|}{6} & \multicolumn{3}{|c|}{7} & \multicolumn{4}{|c|}{8} \\
\hline & & $\mathbf{S B}$ & $\mathbf{B}$ & c: & $\mathrm{TB} / \mathrm{S}$ & SB $\mathbf{B}$ & C & $\mathrm{TB}$ & $\mathrm{SB}$ & \begin{tabular}{l|l}
$\mathbf{B}$ & $\mathbf{C}$ \\
\end{tabular} & \begin{tabular}{l|l|l}
$\mathbf{C}$ & $\mathbf{T I}$ \\
\end{tabular} & $\mathrm{BB}$ & $\mathbf{B}$ & c & $\mathrm{TB} / \mathrm{S}$ & \begin{tabular}{l|l}
$S B$ & $B$ \\
\end{tabular} & $8 \mathrm{c}$ & $\mathrm{TB}$ & SB & B & $\mathbf{c}$ & & & $B \mid c$ & TB & $5 B$ & $\mathbf{B}$ & c: & $\mathrm{IB}$ \\
\hline 1 & Proporsi junl we den vivezz & & & 1 & & & & 1 & & & 1 & & & & \pm & & & + & & & & 1 & & & 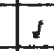 & & & & $t$ \\
\hline 2 & Kebersihun toiletwec & & 1 & & & & & 1 & & 1 & & & & 1. & & & \pm & & & & 1 & & & $d$ & & & & 1 & \\
\hline 3 & Ventilasi rousazelas & 1 & & & & 1 & & & 1 & & & 1 & & & & 1 & & & $t$ & & & & 1 & & & 1 & & & \\
\hline 4 & Tumpat ampah a toilet we & & 1 & & & & & 1 & 1 & & & & 1 & & & & 4 & & & & & $j$ & & \pm & & & & 1 & \\
\hline 5 & Lokasi kantin & & & 1 & & & $j$ & & 1 & & & $J$ & & & & & $j$ & & & & 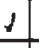 & & $\downarrow$ & & & & & 1 & \\
\hline 6 & B.shan makanin & & $t$ & & & $t$ & & & & $J$ & & & 1 & & & 1 & 1 & & & $J$ & & & & 4 & & & 1 & & \\
\hline 7 & Kabersiban kantin & & 1 & & & & $J$ & & & 1 & & $s$ & & & & 1 & 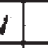 & & & & 1 & & & $t$ & & & 1 & & \\
\hline 8 & Koalitas ait stcars fisik & & 1 & & & 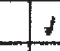 & & & & 1 & & & 1 & & & 1 & 1 & & & 1 & & & & $t$ & & & 1 & & \\
\hline 9 & Salurm pembarngen air limbah & & & $t$ & & & $J$ & & & & 1 & & & 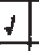 & & & 1 & & & & 1 & & & $d$ & & & & 1 & \\
\hline 10 & Rondist lingkungen sotrolah & $t$ & & & & & $J$ & & $J$ & & & & $\Delta$ & & & $J$ & 1 & & & & 1 & & & 1 & & & 1 & & \\
\hline II & Rasio tempat umpuh & 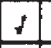 & & & & 1 & & & 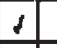 & & & $d$ & & & & 1 & & & 1 & & & & 1 & & & 1 & & & \\
\hline 12 & Penzeloluso sampah wetrolah & & 1 & & & & 1 & & 1 & & & 1 & & & & $J$ & $y$ & & & & 1 & & & 1 & & & 1 & & \\
\hline 13 & Kondivi nang lolas & & 1 & & & 1 & & & 1 & & & & $t$ & & & 1 & 1 & & & & & 1 & & 1 & & & 1 & & \\
\hline 14 & Kepadatan mange kelas & & & 1 & & 1 & & & & & $t$ & 1 & & & & & & 1 & 1 & & & & & & $t$ & & & & 1 \\
\hline 15 & Xtbersihan roang kelus & & 1 & & & 1 & & & & 1 & & & 1 & & & 1 & $y$ & & & & 1 & & & $y$ & & & 1 & & \\
\hline 16. & Pencabryzan & 1 & & & & $\downarrow$ & & & 1 & & & 1 & & & & 1 & & & $d$ & & & & 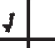 & & & 1 & & & \\
\hline 17 & Kelempatan & & & & 1 & & & $\checkmark$ & & & 1 & & & & 1 & & & $t$ & & & & $J$ & & & 1 & & & & 1 \\
\hline 18 & suhni & & & & 11 & 1 & & & 1 & & & 1 & & & & \pm & & & 1 & & & & & & 1 & 1 & & & \\
\hline 19 & Kerapatan Pohon Peneduh & & & 1 & & & & 1 & 1 & & & & & 1 & & 1 & & & & & 1 & & & 1 & & & 1 & & \\
\hline
\end{tabular}

Keterangan:

SB : Sangat Baik dengan Nilai Skor $=40, B \quad$ : Baik dengan Nilai Skor $=30$

C : Cukup dengan Nilai Skor $=20$, TB : Tidak Baik dengan Nilai Skor $=10$

Tabel 3. Jumlah Skor Survei Sarana dan Prasarana pada delapan SMA di Kota Denpasar

\begin{tabular}{llc}
\hline No & Sekolah & Jumlah Skor \\
\hline 1 & SMAN 1Denpasar & 540 \\
2 & SMAN 2 Denpasar & 480 \\
3 & SMA 3 Denpasar & 630 \\
4 & SMA 4 Denpasar & 590 \\
5 & SMA 5 Denpasar & 540 \\
6 & SMA 6 Denpasar & 470 \\
7 & SMA 7 Denpasar & 550 \\
8 & SMA 8 Denpasar & 530 \\
\hline
\end{tabular}

penyusunan kategori yang memadukan jumlah parameter dengan jumlah skor yang diperoleh. Berdasarkan jumlah skor dari 19 parameter sarana dan prasarana pada masing-masing sekolah, apabila dikategorisasi menjadi empat kategori maka dihasilkan Tabel 4.

Tabel 4. Kategori Tingkat Kenyamanan Lingkungan BelajarBerdasarkan Sarana dan Prasarana

\begin{tabular}{lll}
\hline No & Jumlah Skor & Kategori \\
\hline 1 & $571-760$ & Sangat yaman \\
2 & $381-570$ & Nyaman \\
3 & $191-380$ & Cukup yaman \\
4 & $0-190$ & Tidak yaman \\
\hline
\end{tabular}

Berdsarkan empat kategori tersebut diawali dari menetapkan nilai terendah yaitu 190 kategori tidak nyaman yang diperoleh dari 19 parameter dikalikan dengan nilai skor terendah yaitu 10 sehingga menghasilkan 190. Kategori selanjutnya ditentukan dengan mengalikan jumlah parameter dengan nilai skor 20, 30, dan 40 .

Berdasarkan empat kategori sesuai Tabel 4 bahwa kondisi sekolah dengan jumlah skor di atas 571-760 tergolong sangat nyaman, jumlah skor 381570 tergolong nyaman, 191-380 tergolong cukup nyaman. Sedangkan sekolah dengan jumlah skor di 190 ke bawah tergolong tidak nyaman. Hasil survei menunjukkan SMA Negeri 3 Denpasar tergolong kategori sangat nyaman dan selebihnya tergolong kategori nyaman.

Berdasarkan survei sarana dan prasarana yang di peroleh hasil yang dituangkan dalam grafik seperti gambar 3 .

Gambar 3 menjelaskan bahwa SMA Negeri 3 Denpasar mendapat nilai tertinggi dengan kategori sangat nyaman, karena sarana dan prasarana yang ada di sekolah rata-rata ketersediaannya sangat baik antara lain : jumlah kelas SMAN 3 Denpasar adalah 22 kelas dengan jumlah tempat sampah 32 buah, dimana rasio tempat sampah 1:1, berarti sudah sangat baik. Proporsi jumlah WC terhadap siswa perempuan dan laki-laki cukup baik yaitu 1:39, dimana proporsi standarnya 1:40, Lokasi kantin sekolah cukup baik. Kualitas air secara fisik baik 


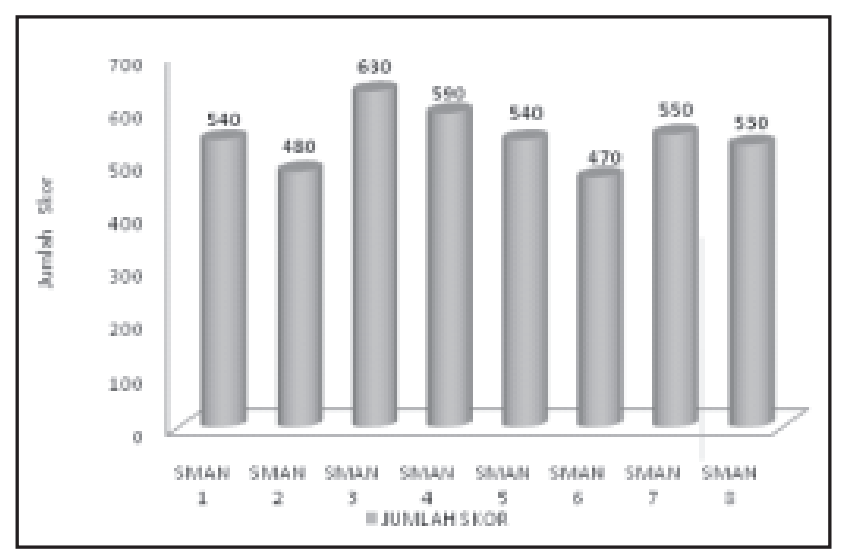

Gambar 3.Grafik Hasil Survei Sarana dan Prasarana Sekolah

dan saluran pembuangan air limbah di alirkan keluar lingkungan sekolah. Kondisi lingkungan sekolah rindang, asri dan bersih. Pengelolaan sampah sekolah baik sekali karena pemilahan dimulai dari pemisahan sampah organik dan anorganik, sampah anorganik dari masing-masiing kelas diangkut ke TPS setiap hari. Sampah di TPS diangkut ke TPA maksimal 1x24 jam. SMA Negeri 3 Denpasar mengolah sampah organik menjadi kompos di tempat khusus dan tidak di halaman sekolah sehingga tidak menggangu keasrian sekolah. Hasil kompos dimanfaatkan kembali untuk kesuburan tanaman di lingkungan SMAN 3 Denpasar. Kondisi ruang kelas sangat baik, untuk ventilasi ruang kelas rata-rata $26,65 \%$ yang berarti sudah memenuhi standar.

SMA Negeri 6 Denpasar mendapat nilai terendah diantara sekolah lain tetapi masih kategori nyaman karena proporsi jumlah WC terhadap siswa perempuan dan laki-laki tidak baik yaitu 1:43, dimana proporsi standarnya yaitu 1:40 dan tidak ada tempat sampah ditoilet. Kebersihan toilet dinilai cukup bersih dengan luas rata-rata $3,4 \mathrm{~m}^{2}$, kondisi lingkungan sekolah kurang nyaman karena ada renovasi pagar pengengker /pengaman sekolah. SMAN 6 Denpasar mempunyai tempat parkir tetapi masih kurang menampung jumlah yang ada. Kondisi ruang kelas kurang baik karena ada beberapa ruang kelas yang tidak layak digunakan untuk proses belajar mengajar seperti jendela yang pecah dan jendela lubang tanpa kaca, daridelapan sekolah hanya SMA Negeri 6 Denpasar yang belum menggunakan kipas angin ataupun AC.

\subsection{Suhu, Kelembaban dan Pencahayaan}

Hasil pengukuran di SMA Negeri 2 Denpasar suhunya tertinggi dari sekolah lain karena pada saat melakukan pengukuran pada tanggal 6 Maret 2015 pukul 08.45 - 09.25 wita cuaca cerah dan sinar matahari terang sehingga suhu rata-rata $28,60^{\circ} \mathrm{C}$ dapat dilihat pada lampiran 25 , sedangkan suhu terendah di SMA Negeri 4 Denpasar yaitu $23,50^{\circ} \mathrm{C}$ karena ruang kelas menggunakan $\mathrm{AC}$ sebanyak dua buah dengan kekuatan 1 PK. Hasil pengukuran suhu yang dilakukan di delapan sekolah masih nyaman hal ini dapat dibandingkan dengan berbagai penelitian kenyamanan suhu yang dilakukan di daerah iklim tropis basah seperti halnya Mom (1937) dan Wiesebron (1950) di Bandung, Ellis (1953), de Dear (1990) di Singapura, Busch (1988) di Bangkok, Ballabtyne (1967 dan 1979) di Port Moresby, kemudian Karyono (1993) di Jakarta dalam (Basaria $\mathrm{T}, 2005)$, memperlihatkan tentang rentang suhu antara $24^{\circ} \mathrm{C}$ hingga $30^{\circ}$ Cyang dianggap nyaman bagi manusia yang berdiam pada daerah iklim tersebut.

Kelembaban tertinggi pada SMA Negeri 5 Denpasar 84,48\%, dimana SMA Negeri 5 Denpasar memiliki luas lahan paling luas yaitu $25.000 \mathrm{~m}^{2}$ dengan luashalaman dan kebun $12.541 \mathrm{~m}^{2}$. Ruang terbuka hijau (RTH) berfungsi sebagai peneduh yang akan menciptakan kenyamanan karena unsur vegetasi berupa pohon misalnya dapat memodifikasi iklim mikro yaitu penurunan suhu dan peningkatan kelembaban udara (Nursanti dan Elly IS, 2013). Kerapatan vegetasi di areal SMAN 5 Denpasar mengakibatkan banyaknya tutupan lahan sehingga sinar matahari tidak sampai pada muka tanah meskipun pengukuran dilakukan pukul 11.00-11.30 wita sehingga kelembaban meningkat, hal ini masih nyaman karena menurut (Basaria T, 2005) Indonesia mempunyai iklim tropis dengan karakteristik kelembaban udara relatif tinggi, dapat mencapai angka $80 \%$. Sedangkan kelembaban terendah pada SMA Negeri 2 Denpasar yaitu 68,43\% terjadi karena vegetasi yang kurang diareal sekolah dan halaman sekolah yang berdebu dan kering karena pembangunan gedung yang ada di areal sekolah.

Pencahayaan tertinggi di ruang kelas yaitu pada SMA Negeri 8 Denpasar dengan rata-rata 597,0 lux, karena ruang kelas rata-rata disebelah kanan dan kirinya adalah halaman sekolah. Sedangkan pencahayaan terendah pada SMA Negeri 2 Denpasar, karena ruang kelas terhalang tembok pengaman yang tinggi di selatannya sehingga ruang kelas tidak terang oleh pencahayaan alami (sinar matahari) dan memperoleh 190,4 lux, ruang kelas bisa lebih terang oleh penerangan bola lampu. Dalam SNI 03-65752001 yang mengacu kepada Standar National Electric Code (NEC), Iluminating Engeneering Society (IES), International Electrotechnical Commision (IEC) dan Australian Standard (Widyaningrum N D, 2014) di sebutkan tingkat terang yang direkomendasikan di titik pandang ruang kelas adalah sekitar 250 Lux dan hasil pengukuran menunjukkan diatas $250 \mathrm{Lux}$.

\subsection{Persepsi Siswa}

Berdasarkan persepsi siswa di sekolah yang dipandang paling nyaman dari delapan SMAN di Kota Denpasar adalah SMAN 3 Denpasar sebesar $62,85 \%$ dengan pernyataan tidak nyaman $0 \%$, dan sekolah tidak nyaman pada SMAN 6 Denpasar sebesar 11,43\%. Sarana dan prasarana di SMAN 6 Denpasar kurang optimal seperti ada kaca yang pecah dan jendela tanpa kaca (lubang), juga tidak 
ada kipas angin atau AC yang digunakan di ruang kelas.

SMA Negeri 2 Denpasar juga menyatakan persepsi siswa tidak nyaman sebesar $2,86 \%$ karena perilaku siswa kurang ramah lingkungan, seperti terdapat dua tempat sampah untuk sampah organik dan nonorganik tapi kenyataannya sampah dibuang tidak berdasarkan tempat sampahnya. Toilet tidak bersih sehingga bau menyengat tersebar sampai keluar toilet. Perilaku siswa membuang sampah sembarangan terlihat pada kolam ikan yang tidak terawat.

\section{SIMPULAN DAN SARAN}

\subsection{Simpulan}

Tingkat kenyamanan lingkungan belajar SMA Negeri di Kota Denpasar berdasarkan tingkat kebisingan telah melebihi baku mutu $55 \mathrm{~dB}$, dengan kebisingan tertinggi terjadi di halaman sekolah sebesar 73,0 dB, dengan penyebab utamanya adalah kendaraan bermotor. Suhu dan kelembaban udara tidak berpengaruh terhadap tingkat kenyamanan, karena masih memenuhi standar. Pencahayaan ruang kelas di delapan SMAN di Kota Denpasar sangat baik karena sudah memenuhi baku mutu.

Ketersediaan dan pengelolaan sarana dan prasarana yang sudah optimal dan memadai memberikan dukungan yang sangat besar di semua SMAN di Kota Denpasar. Dukungan sarana dan prasarana terlihat nyata pada SMAN 3 Denpasar. Hampir semua siswa di delapan SMAN di Kota Denpasar menyatakan bahwa lingkungan sekolahnya adalah nyaman, bahkan SMAN 3 Denpasar menyatakan sangat nyaman sebesar $62,85 \%$.

\subsection{Saran}

1. Untuk mengurangi pengaruh kebisingan terhadap tingkat kenyamanan belajar siswa di perlukan penanaman pohon pada pagar sekolah yang berfungsi sebagai peredam kebisingan seperti menanam pohon bambu jakarta atau bambu kuning.

2. Disarankan memperhatikan perawatan sarana dan prasarana sekolah berupa keberlanjutan pengelolaan sarana dan prasarana yang memadai.

3. Pemilihan lokasi sekolah perlu memperhatikan faktor kebisingan.

\section{DAFTAR PUSTAKA}

Basaria, T. 2005. Menciptakan Kenyamanan Thermal dalam Bangunan.Jurnal Sistem Tehnik Industri, Volume 6 No. 3 Program Studi Arsitektur Universitas Sumatera Utara.

Keputusan Menteri Kesehatan Republik Indonesia Nomor: 1405/MENKES/SK/XI/2002 tentang
Persyaratan Kesehatan Lingkungan Kerja Perkantoran dan Industri.

Maknun, J.; Hananto, Busono. 2010. Pengaruh Kebisingan Lalu Lintas terhadap Efektifitas Proses Belajar Mengajar (Studi Kasus pada sekolah Menengah Atas Negeri 6 Bandung.Jurnal Jurusan Pend.Teknik Arsitektur FPTK Universitas Pendidikan Indonesia.

Nursanti dan Elly IS. 2013. Potensi Keanekaragaman Hayati,Iklim dan Serapan Karbon pada Ruang Terbuka Hijau Kampus Mendalo Universitas Jambi.Jurnal Fakultas Pertanian, Universitas Jambi, Mendalo Darat, Vol.2 No. 2 April-Juni 2013.

Direktorat Penyehatan Lingkungan DIRJEN PPM dan PL DEP.KES. RI. 2004. Pedoman Teknis Pengendalian Faktor Resiko Kesehatan Lingkungan di Sekolah.

Peraturan Menteri Negara Lingkungan Hidup RI Nomor: 01 Tahun 2013 tentang Perubahan Atas Peraturan Menteri Negara Lingkungan Hidup Nomor: 07 Tahun 2011 tentang Pedoman Pelaksanaan Program Adipura.

Peraturan Gubernur Bali Nomor: 8 Tahun 2007 tentang Baku Mutu Kebisingan Provinsi Bali.

Prawira A. P. 2011. Tingkat Pencemaran Udara Kawasan Sekolah Berdasarkan Parameter Total Suspended Particulate (TSP) dan Kebisingan Akibat Kendaraan yang melintas (Studi Kasus : SMP 29, SMP11 Dan SMP 19 Jakarta Selatan). Skripsi Fakultas Tehnik Universitas Indonesia.

Shield B. M and J. E Dockrell. 2003.The Effects Of Noise On Children At School, Division Of Building Service, Faculty of Engineering Science and Techology, South Bank University,London SEI OAA and Psychology and Human Development, Institute Of Education, London University,25 Waburn Square, London WC1H OAA(32,33).

Sri Indah K. 2010. Hubungan Antara Tingkat Kebisingan dengan Gangguan Stres Masyarakat Di Pemukiman Sekitar Rel Kereta Api Srago Gede.Jurnal Prodi DIII Kesehatan Lingkungan STIKES Muhammadiyah Klaten.

Widyaningrum N.D.; Wahyuni S. 2014. Perfoma Penerangan Interior Ruang Kelas Politehnik Negeri Jakarta Menuju Standar Internasional, Jurnal Jurusan teknik Sipil Politehnik Negeri Jakarta (PNJ) Kampus Baru UI Depok 16425.

Widyantoro B.; Mohammad R. 2011. Pemetaan Tingkat Kebisingan Akibat Aktivitas Transportasi Dikaitkan dengan Tata Guna Lahan di Jl. Arif Rachman Hakim Surabaya, Jurnal Jurusan Tehnik Lingkungan F TSP-ITS. 